\title{
IMPLEMENTASI PENDEKATAN FENOMENOLOGIS DALAM PENELITIAN PENDIDIKAN
}

\begin{abstract}
Oleh:
Suranto AW

FISE UNY

\section{Abstrak}

Dalam rangka meningkatkan kualitas pendidikan pada gradasi yang lebih tinggi, maka setiap upaya meningkatkan kualitas pendidikan perlu dilakukan melalui penelitinan. Supaya penelitian dapat memberikan informasi atau temuan yang akurat, maka perlu menggunakan metode penelitian yang tepat. Fenomenologi merupakan salah satu alternatif pendekatan untuk diimplementasikan dalam rangka melakukan penelitian dan kajian keilmuan kependidikan. Calam pandangan fenomenologi, gejala proses pendidikan itu bersifat holistik (menyeluruh, tidak dapat dipisah-pisahkan), sehingga peneliti tidak akan melaksanakan penelitiannya hanya berdasarkan variabel, tetapi keseluruhan gejala empiris itu, meliputi aspek tempat (olace), pelaku (actor), dan aktivitas (activity) yang berinteraksi secara sinergis. Implementasi pendekatan fenomenologis telah menambah variasi metodologi riset untuk memahani persoalanpersoalan pendidikan, sehingga pada akhirnya diperoleh temuantemuan aktual guna meningkatkan pembaharuan pelayanan publik termasuk pendidikan.
\end{abstract}

Kata Kunci : Metode Penelitian, Fenomenologis

\section{Pendahuluan}

Fenomenologi merupakan suatu metode pemikiran untuk memperoleh pengetahuan baru atau mengembangkan pengetahuan yang ada dengan menggunakan langkah-langkah yang logis, sistematis kritis, tidak berdasarkan apriori/prasangka, dan tidak dogmatis. Fenomenologi se- bagai sebuah metode atau pendekatan, tidak hanya digunakan dalam filsafat, melainkan juga dalam berbagai macam ilmu sosial, termasuk ilmu pendidikan.

Permasalahannya adalah bahwa pendekatan fenomenologis belum cukup populer dalam penelitian pendidikan apabila 
dibandingkan de-ngan pendekatan positivistik. Secara historis tradisi riset sosial dan pendi-dikan relatif lebih muda dibandingkan dengan riset ilmuilmu alam (eksakta). Ada asumsi bahwa ilmu pengetahuan itu tersusun secara hirarkis: sains, il-mu sosial, humaniora, keterampilan fisik. Metodologi riset ilmu pasti alam (positivistik) sudah lebih dahulu dikenal luas oleh kalangan akademisi sebagai sebuah pendekatan ilmiah yang memadai. Konsekuensi dari kenyataan ini adalah bahwa dalam upaya mengangkat derajat riset pendidikan, seringkali dilakukan dengan menerapkan paradigma riset ilmu-ilmu alamiah (perspektif mekanistik, hard system, dan positivistik).

Begitu banyak penelitian nendidikan yang dikerjakan dengan pendekatan positivistik, dimana variabel-variabel pendidikan itu diletakkan dalam pola hubungan linier dan dianalisis secara kuantitatif. Akibatnya terjadi berbagai kontroversi sebagai berikut.

a. Perspektif yang positivistik "merajalela" dan mendominasi metodologi penelitian pendidikan. Model-model riset pendidikan yang linier demikian populer, padanal suatu model sering menunjukkan kekurangan-kekurangan mengenai karakteristik fenomena yang dimodelkan.

b. Banyak peneliti pendidikan yang positivis secara apriori menolak metode penelitian pendidikan yang humanistik. Padahal se- benarnya, keistimewaan ilmu sosial (termasuk ilmu pendidikan) justru karena keaneka-ragaman perspektifnya. Objek ilmu-ilmu alam yang statis dan tidak mempunyai kemauan bebas jelas berbeda dengan objek ilmu sosial dan pendidikan, yakni manusia yang mempunyai jiwa dan kemauan bebas. Keanekaragaman perspektif riset sosial dan pendidikan ini terutama disebabkan kompleksnya fenomena perilaku sosial dan proses pendidikan. Sayangnya terjadinya penolakan tersebut seringkali berdasarkan arcgansi akademik semata-mata.

c. Dominasi paradigma positivistik dalam riset sosial dan pendidikan telah mengakibatkan suatu efek samping, ialah bahwa para peneliti positivis cenderung menganggap metode merekalah yang lebih unggul untuk mengkaji fenomena sosial dan pendidikan. Seorang mahasiswa $\mathbf{S 1}$ kependidikan di sebuah universitas kepada kami mengaku usulan/ proposal skripsinya ditolak karena hanya terdapat satu variabel, bukan dua variabel atau lebih. Ketika seorang calon sarjana S1 memperiahankan skripsi dengan pendekatan kualitatii, tidak jarang para penguji positivis ini menilai 
karya penelitian tersebut dengan menggunakan standar positivistik. "Mana variabel bebasnya dan variabel terikatnya?". Padahal dalam penelitian kualitatif, istilah variabel sendiri tidak begitu dikenal.

d. Dalam pengajaran metodologi penelitian sosial maupun pendidikan, mahasiswa lebih banyak diajari pendekatan positivistik. Misalnya dalam struktur kurikulum ada matakuliah Pengantar Statistika dan Statistika Lanjutan, Metode Penelitian Sosial, Metode Penelitian Pendidikan.

e. Di beberapa universitas, pengajaran metodologi penelitian diberikan oleh dosen-dosen yang berlatarbelakang pendidikan ilmu-ilmu alam.

Dalam tulisan ini, dirasa perlu dibahas mengenai betapa pentingnya pendekatan fenomenologis dalam riset pendidikan. Adalah suatu fenomena yang membanggakan ketika dewasa ini secara lambat namun pasti, telah pula berkembang riset pendidikan berbasis pendekatan humanistik (fenomenologis, interaksionis, kritis, interpretif, dan soft system).

Mengingat hal tersebut kita perlu mengenal lebih dekat, apakah sebetulnya fenomenologi itu?, Siapakah tokoh-tokoh yang mengembangkannya?, Bagaimanakah karakteristik fenomenologi untuk membedakannya dengan metode yang lain? Bagaimanakah metode itu diimplemen- tasikan dalam penelitian dan pengemhangan pendidikan?

\section{Pengertian Fenomenologi}

Kata fenomenologi berasal dari bahasa Yunani, yaitu phainomenon, yang arti harfiahnya adalah menampakkan atau memperlihatkan. Drijarkara dalam bukunya "Percikan Filsafat" menyatakan bahwa fenomenologi tersusun dari dua istilah yaitu fenomenon dan logos. Fenomenon adalah sesuatu yang nampak, sedangkan logos ialah ilmu. Dengan demikian fenomenologi ialah ilmu atau metode untuk memahami sesuatu yang tampak, teramati, fakta inderawi, atau dalam istilah sehari-hari disebut gejala.

Noeng Muhadjir ( $2006: 164$ ) mengatakan bahwa logika phenomenologi menghimpun bukti esensial dari phenomera yang momot intensionalitas untuk dasar membuat analisis dan kesimpulan kebenaran. Sementara itu $R$. Small (dalam John P. Keeves and Grabriele Lakomski, 1999 : 256) mengatakan fenomenologi adalah suatu metode filsafat yang dibangun oleh Edmund Husserl untuk memahami suatu fenomena fisik. Gutheng Prabowc (Agus Salim, 2006: 167) mengatakan bahwa fenomenologi adalah bagian dari metodologi kualitatif yang cenderung menentang objektivisme atau positivisme yang telah tumbuh meluas dalam ilmu pengetahuan modern. 
Jadi, fenomenologi berarti suatu metode, pendekatan, uraian, atau percakapan tentang fenomena, atau tentang suatu gejala.

Fenomenologi merupakan paradegma filosofis, yaitu suatu metode pemikiran (a way of looking at thing) (Browner, 1984). Atau merupakan sliatu ilmu. Seorang ahli bisa meyakinkan lawannya dengan memakai bukti seperti hasil eksperimen atau hasil hitungan. Sementara fenomenomogi tidak hanya menarik karena menjelaskan banyak hal yang sulit dilihat, tetapi juga mampu menjelaskan makna di sebalik gejala itu. Misalnya Fonomena mudik lebaran, fenomenologi tidak sekedar mendeskripsikan bagaimana prosesi mudik itu, melainkan hendak menjelaskan pula mengapa orang mudik? Apakah makna sesungguhnya di balik mudik lebaran itti?

Perspektif fenomenologi menempati kedudukan seritral dalam metodologi penelitian kualitatif, apa yang dicari peneliti dalam kegiatan risetnya, bagaimana melakukan dalam situasi riset, dan bagaimana peneliti menafsirkan makna hasil risetnya, bagaimana kaitannya dengan perspektif teoritis yang digunakannya.

Fenomenologi mengganggap dirinya mengetahui makna dari berbagai idologi memandang perilaku manusia, apa yang mereka katakan dan lakukan adalah suatu produk bagaimana orang melakukan tafsir terhadap dunia mereka sendiri, de-ngan kata lain fenomenologi ber-usaha memahami perilaku dari segi kerangka berpikir maupun cara bertindak orang-orang itu sendiri.

Riset dengan pendekatan fenomenologi berusaha memahami makna dari berbagai peristiwa dan interaksi manusia dalam situasinya yang khusus. Untuk menangkap proses diperlukan apa yang disebut oleh Weber (Verstehen) yang artinya peneliti tak mengganggap dirinya mengetahui makna dari berbagai hal pada orang yang sedang dipelajarinya. Oleh karena itu peneliti berusaha berempati atau merasa berada di dalam diri orang lain yaitu kemampuan untuk memproduksi diri didalam pikiran orang lain, perasaan, motif yang menjadi latar belakang kegiatannya. Dengan kata lain untuk menangkap makna perilaku seseorang, peneliti berusaha mengalami atau merasakan apa yang dialami oleh orang lain itu.

Para penganut fenomenologi percaya bahwa ada berbagai cara bagi manusia untuk menginterpretasikan pengalamanya sehari hari lewat interaksi dengan orang lain, dan dari pengalaman itulah tersusun realita. Oleh karena itu, realitas terbentuk dari interaksi sosial. Atas dasar tersebut riset fenomenologi bertujuan mendapatkan pengertian atas subyeknya dari pandangan subyek itu sendiri. Dengan demikian sebetulnya fenomenologi merupakan salah satu metode yang digu-nakan dalam riset dengan 
melalui fa-se dan fepomena dalam masyarakat dan interaksi soial yang tejjadi dida-lamnya. Fenomenologi sebagai meto-de tidak bisa hilang dan bahkan men-jadi sarat mutlak bagi seseorang yang mau memikirkan betapa pentingnya memahami suatu gejala secara ho-listik.

\section{Sejarah Perkembangan Fenome- nologi}

Fenomenologi adalah hasil refleksi pemikiran filosofis dari Edmund Husserl di Jerman pada sekitar tahun 1890-an. Husserl dilahirkan di Prosswitz (Moravia) pada tahun 1859. Filsafat Husserl mengalami perkembangan yang agak lambat, karena filsafatnya itu merupakan kritik dari filsafat positivisme yang sudah terlebih dahulu memasyarakat. Semula ia belajar ilmu pasti di Wina hingga tahun 1881 dan dipercaya menjadi asisten dosen di universitasnya. Kemudian ia tertarik kepada soal-soal filosofis, sehingga ia berpindah studi dari ilmu pasti ke ilmu filsafat dan berguru pada Brentano (1884 -1889) sehingga filsafatnya dipengaruhi oleh gurunya itu. Banyak sekali hasil karyanya, salah satunya adalah I deen Zu Einer Reinen Phanomenologic (Ide-ide bagi suatu Fenomenologi yang murni).

Husserl memakai istilah fenomenologi untuk menunjukkan metode berpikir tepat yang khusus. la memfokuskan atau mengkonsentrasikan analisis fenomenologinya tentang intensitas yaitu semua bentuk kesa- daran dan pengalaman langsung. Seperti pengalaman religius, moral, estetis, konseptual, dan inderawi. Fenomeno!ogi mengadakan refleksi mengenai pengalaman !angsung atas suatu gejala atau fenomena. Dengan refleksi tersebut diharapkan mendapatkan pengertian yang benar dan yang sedalam-dalamnya. Pengertian yang benar adalah pengertian yang menangkap realitas suatu gejala. Sedangkan pengertian yang sedalam-dalamnya, ialah bahwa gejala tersebut dapat difahami sampai kepada makna hakikinya.

Menurut Denzin (1994) fenomenologi Husserl ini dalam perkembangan berikutnya menjadi salah satu metode penelitian kualitatif, dipergunakan di dalam berbagai bidang keilmuan, dan tersebar ke berbagai negara. Banyak ahli yang mengadopsi dan mengembangkan fenomenologi ini ke dalam paradigma penelitian kualitatif. Ambil contoh, Alfred Schultz, dengan pendekatan interpretive praktis telah menjadi tokoh kunci yang merintis social phenomenology dengan fenomenologi filsafat dari Husserl. Pada pendekatan ini, subyektivitas dipandang sebagai titik kunci untuk membuat objek atau gejala menjadi bermakna. Di sinilah metode kualitatif mulai menunjukkan bentuknya sehingga kemudian dapat digunakan sebagai metode penelitian. 
Gutheng Prabowo (Agus Salim, 2006: 171-172) mengatakan bahwa pada awal perkembangannya, fenomenologi dicirikan oleh descriptive phenomenology, yakni pembuktian secara deskriptif atas dua bentuk temuan: (i) permasalahan, dan (ii) objek sebagai permasalahan. Pembagian ini berpengaruh pada terbentuknya empat percabangan besar yang dikenal dalam fenomenologi, yaitu:

a. Realistic Phenomenology: percabangan ini menekankan pencarian persoalan realistik universal manusia ditinjau dari berbagai objek yang meliputi tindakan, motif tindakan, serta nilai kepribadian. Bahwa realitasnya, manusia itu makhluk yang multi dimensional. Untuk mengenalinya, tidak cukup hanya mielihat pendapatnya, persepsinya, pakaiannya, dsb. Tetapi banyak sekali objek yang menentukan siapa sebenarnya manusia yang kita hadapi itu. Kita dapat melihatnya dari aspek hukum, etika, agama, budaya, dsb. Jadi memahami persoalan manusia secara realistis, mesti dilakukan secara multi disiplin. Iklim kontribusi pemikiran lintas disiplin ini kemudian mengedepankan nama-nama ilmuwan fenomelogi realistis, seperti Alexander Pfander, Herbert Spielberg, Karl Schuhman, dan Bari Smith. b. Constitutive Phenomenology: Percabangan ini dimulai dari keraguan terhadap penerimaan status kehidupan kesadaran sebagai hal yang ada di dunia. Ada persoalan-persoalan yang tidak dapat dijelaskan secara logis dan tuntas, karena itu aliran ini mengangkat kajian sampai memikirkan adanya kekuatan transendental, sebagai suatu keniscayaan (trancendental pnenomenological). Tokohtokoh yang mengembangkan percabangan ini antara lain Oskar Becker, Aron Gurwitsch, dan Elizabeth Stoker.

c. Existential Phenomenology: Percabangan ini bermula dari pemikiran Martin Heidegger bahwa manusia pada hakekatnya memiliki kecenderungan untuk mempertahankan eksistensinya. Selain Martin Heidegger, Hannah Arendt juga menggunakan fenomenologi eksistensial dengan kecenderungan kajian pada topik-topik seperti indak kekerasan, konflik, kerinduan, keterbatasan, kekuasaan, dan lain-lain. Disamping Arendt, masih banyak tokoh yang mengembangkan fenomenologi eksistensial seperti dalam isu-isu gender, kebebasan, demokrasi, HAM, dan sebagainya. 
d. Hermeneutical Phenomenology: Hermeneutik berasal dari bahasa Yunani hermenia yang berarti penafsiran. Arti lain dari hermeneutik adalah "hermeneuin" yang berarti menjelaskan. Noeng Muhadjir (2006: 154) menjelaskan bahwa hermeneutik itu arti harfiahnya adalah the arts of understanding. Ada hermeneutik bahasa dan hermeneutik fenomena. Hermeneutik bahasa bermaksud memahami suatu gejala dari bahasanya, baik lisan maupun tulisan. Hermeneutik fenomenologik ingin mengetahui makna suatu gejala dari cejala itu sendiri yang dikaji secara mendalam. Hakekat dari metode hermeneutik adalah pada metode interpretasi. Betapa banyak 'fenomena pendidikan yang membingungkan karena tidak ada kesepahaman. Karena renafsiran tidak sampai pada tahap "verstehen" atau mudheng. Jalan untuk memahami secara mendalam suatu fenomena itu tidaklah mudah. Apalagi jika fenomena tu telah terjadi bertahun-tahun atau bahkan berabad-abad silam seperti dalam sejarah, cerita-cerita lama, atau pun wahyu Tuhan yang disampaikan berabadabad yang lalu yang termuat dalam kitab suci. Manusia perlu menafsirkan. Bahkan dalam pergaulan hidup sehari-hari selalu saja ada fenomena psikis yang belum dipahami, sehingga memerlukan penafsiran. Betapa banyaknya salah paham dalam pergaulan antarsesama teman atau bahkan anggota keluarga, hal ini disebabkan penafsiran terhadap fenomena tingkah laku atau perkataan dari orang-orang yang dekat dengan diri kita seringkali tidak dapat secara cermat karena keterbatasan kita. Orang-orang yang tergolong "muka badak" atau "kepala batu", sulit menafsirkan fenomena yang disampaikan melalui simbol atau kiasan. Sebaliknya orang yang sensitif cenderung lebih mampu memahami dan menafsirkan fenomena yang terjadi, meskipun fenomena itu diungkapkan dengan simbol-simbol.

\section{Karekteristik Fenomenologi}

Setiap aliran filsafat memiliki karakteristik yang unik sehingga dapat dipergunakan untuk membedakan dengan aliran lainnya. Antara satu aliran dengan yang lainnya, memiliki kelebihan dan kekurangan sesuai konteksnya. Berikut ini disajikan beberapa karakteristik fenomenologi.

a. Kritik terhadap positivisme 
Sebagaimana diungkapkan oleh Husserl bahwa setelah ia mendalami ilmu pasti, ternyata ada berbagai kegelisahan yang menyebabkan dirinya berkonsentrasi pada fenomenologi. Fenomenologi Husserl merupakan kritik atas positivisme. Filsafat positivisme ternyata sangat menekankan segi rasional ilmiah, baik pada epistimologi, maupun pada keyakinan ontologik yang dipergunakan sebagai dasar pemikirannya. Bagi penganut positivisme, hanya ilmu pengetahuan positiflah yang dianggap mampu untuk menerangkan kenyataan, sedemikian rupa keyakinan meraka akan kebenaran pandangannya, sehingga melalui ilmu pengetahuan positif mereka mengira telah dapat menjangkau seluruh kenyataan. Dengan terlalu mendambakan ilmu pengetahun positif sebagai satu-satunya ilmu yang dianggap mampu mencapai kebenaran, ternyata pandangan positivisme telah mereduksikan men"detotalisasi" kan objeknya, termasuk manusia dan alamnya. Faham positivisme hanya mampu melihat manusia sebagai realitas bendawi tanpa mampu menjangkau segi-segi subjektivitas "aku" dalam seluruh pengalaman, pengertian, kedudukan, ataupun sikap dalam kehidupan eksistensial. Faham positivisme dipanddang tidak mampu menghayati manusia dalam hakikatnya yang "monopluralistik", yaitu kesatuan atau keutuhan organik dari unsur-unsur fisik-kimiawi, vegetatif animal (biologik), dan berakal, berasa, berkehendak.

\section{b. Mazab interpretif}

Fenomenologi merupakan mahzab interpretif. Filsafat fenomenologi berkeyakinan bahwa manusia adalah makhluk yang dapat menginterpretasi. Meaning selalu dipengaruhi oleh interpretasi. Dengan demikian untuk dapat menarik suatu kesimpulan, harus diiakukan interpretasi atas data. Data kualitatif tidak pernah bersifat "nomotetik" (satu data satu makna) seperti dalam pendekatan kuantitatif atau positivisme. Karena itu, menurut pendekatan fenomenologi, suatu gejala atau data harus diinterpretasi dengan benar.

\section{c. Kebenaran itu subjektif}

Fenomenologi menggunakan strategi interpretive praktice untuk mencari kebenaran. Peneliti memiliki peran penting dalam menghasilkan kebenaran sesuai dengan interpretasinya atas data. Dengan demikian kebenaran bisa bersifat subjektif, ketika interpretasi itu tidak dapat diterima secara umum. Itulah sebabnya fencmenologi menyadari bahwa kebenaran itu bersifat subyektif.

d. Berpikir induktif, teratur, keajegan.

Dalam fenomenologi, proses berpikir mengikuti proses penalaran induktif. Jujun $S$ Suriasumantri (1999: 48) mengatakan induktif merupakan cara berpikir dimana 
ditarik suatu kesimpulan umum dari berbagai kasus yang bersifat individual. Penalaran secara induktif dimulai dengan mengemukakan pernyataan-pernyataan yang mempunyai ruang lingkup yang khas dan terbatas dalam menyusun argumentasi yang diakhiri dengan pernyataan yang bersifat umum.

Dalam penelitian kualitatif fenomenologik, data dikumpulkan dari kasus yang bersifat individual. Kesimpulan diperoleh setelah peneliti sudah melihat terjadinya keteraturan, dan keajegan data. IImu pengetahuan pun diperoleh setelah terjadi pola yang terautur mengenai kejadian. Suatu benda padat kalau dipanaskan akan memuai. Langit mendung diikuti turunnya hujan. Begitu seterusnyả kita akan memperoleh pengetahuan mengenai berbagai gejala yang mengikuti pola keteraturan dan keajegan tertentu.

e. Mengkaji wacana dan gejala dalam kehidupan sehari-hari

Fenomenologi mengkaji gejalagejala yang secara empiris ada di dalam kehidupan masyarakat seharihari. Tidak melakukan manipulasi atau treatment khusus atas data, melainkan apa adanya data itu dipelajari sesuai situasi alamiah (naturalistic inquiry). Agus Salim (2006: 167) mengatakan bahwa fenomenologi cenderung mengkaji "apa adanya seperti itu". f. Peneliti merupakan instrumen utama

Bahwa fenomenologi menganggap peneliti merupakan instrumen yang paling baik untuk pengumpulan data. Untuk mengetahui "proses" suatu pokok kajian, peneliti melakukan kontak personal langsung di seting lapangan penelitian. Dengan demikian peneliti memiliki kedekatan dengan subjek, dan dengan kedekatan itulah dapat diperoleh temuan yang sesuai dengan kenyataan.

g. Perspektif holistik

Holistik artinya menyeluruh. Fenomenologi bergerak dari asumsi bahwa fenomena merupakan suatu jalinan yang utuh dan kompleks. Oleh karena itu suatu totalitas dipandang lebih berharga dari pada hanya mengkaji satu variabel secara parsial.

Implementasi Pendekatan Fenomenologis dalam Penelitian Pendidikan

IImu pengetahuan berkembang sesuai dengan perkembangan kebutuhan manusia. Kebutuhan manusia juga mengalami perkembangan seiring dengan perkembangan kehidupan. Dengan demikian manusia selalu berupaya untuk menemukan landasan pikiran baru untuk mengantisipasi perubahan dan perkembangan kebutuhan berdasarkan disiplin metodologi ilmiah. 
Ilmu pengetahuan berkembang dari rasa ingin tahu, dan upaya khusus manusia untuk menyikapi realitas yang ada di alam ini. Begitupula dengan dinamika perkembangan ilmu pendidikan senantiasa dipengaruhi oleh rasa ingin tahu, rasa penasaran dari para pelaku pendidikan sehingga dilaksanakan berbagai riset sistematis. Dalam rangka meningkatkan kualitas pendidikan pada gradasi yang tinggi, maka setiap upaya meningkatkan kualitas pendidikan perlu dilakukan melalui penelitinan. Supaya penelitian dapat memberikan informasi atau temuan yang akurat, maka perlu menggunakan metode penelitian yang tepat.

Fenomenologi merupakan salah satu alternatif pendekatan untuk diimplementasikan dalam rangka melakukan penelitian dan kajian keilmuan kependidikan. Sebagai suatu alternatif, pendekatan fenomenologi sudah semestinya memiliki ciri-ciri unik yang membedakannya dengan pendekatan lain. Namun demikian, menurut Agus Salim (2006: 3) pada fase awal pengembangan cara analisis masih menunjukkan "sisa-sisa" positivisme.

Riset pada hakekatnya merupakan wahana untuk menemukan kebenaran atau untuk lebih membenarkan suatu kebenaran. Upaya untuk mendapat kebenaran tersebut dilakukan oleh para filosof dan peneliti melalui metode tertentu atau model tertentu yang biasa dikenal dengan paradigma.

Kalau kita membandingkan implementasi pendekatan positivisme dengan fenomenologi, maka nampak jelas bahwa dalam positivisme (kuantitatif) gejala dari suatu objek itu sifatnya tunggal dan parsial. Dengan demikian berdasarkan gejala tersebut peneliti kuantitatif dapat menentukan variablevariabel yang akan diteliti. Namun dalam pandangan fenomenologi, gejala proses rendidikan itu bersifat holistik (menyeluruh, tidak dapat dipisah-pisahkan), sehingga peneliti tidak akan melaksanakan penelitiannya hanya berdasarkan variabel, tetapi keseluruhan gejala empiris itu, meliputi aspek tempat (place), pelaku (actor), dan aktivitas (activity) yang berinteraksi secara sinergis. Gejala empiris ini apabila yang kita bahas terkait dengan masalah pendidikan, misalnya secara terfokus yang diteliti adalah proses pembelajaran di kelas, maka fenomenologi berusaha memahami secara holistic menyangkut situasi sosial di dalam kelas (place), guru dan murid (actor), dan aktivitas proses belajar mengajar (activity).

Implementasi pendekatan fenomenologis telah menambah variasi metodologi riset untuk memahami persoalan-persoalan pendidikan, sehingga pada akhirnya diperoleh temuan-temuan aktual guna meningkatkan pembaharuan pela- 
yanan publik termasuk pendidikan. Dengan implementasi pendekatan fenomenologis semakin memperkuat peranan riset dalam pendidikan. Pada giliran berikutnya implementasi fenomenologi dalam riset pendidikan ini memiliki berbagai peran strategis, dan dijelaskan lebih rinci berikut ini.

a. Pengembangan ilmu dan ilmu pendidikan. Artinya, penelitian-penelitian pendidikan ditujukan untuk kepentingan pengembangan ilmu pendidikan itu sendiri termasuk ilmu-ilmu bantunya. Masalah dan variabel yang diteliti digali dan diangkat berdasarkan teoriteori yang ada dalam ilmu pendidikan. Jadi riset berusaha mamahami fenomena empirik dan teoritik yang senantiasa berubah, bukan saja menyentuh perilaku yang tampak tetapi tak lepas dari filosofi yang mendasari, misalnya aneka liberaliśme, Jan esensialisme.

Hipotesis dicoba diturunkan dari teori yang ada, diuji secara empirik dengan harapan muncul teori baru atau penyempurnaan teori yang ada. Sekurang-kurangnya menguji teori yang telah ada, untuk menemukan kondisi-kondisi tertentu yang paling memungkinkan penerapiannya dalam praktik pendidikan, baik pada level individual maupun organisational. Dengan demikian fungsi dan peran riset adalah untuk pengembangan ilmu dan ilmu pendidikan agar senantiasa aktual dan responsif terhadap perubahan-perubahan, baik dalam tataran individual maupun organisational. $\mathrm{Pa}$ da giliran berikutnya riset mampu memberikan kontribusi dalam pelayanan publik termasuk pendidikar.

2. Pemecahan masalah pendidikan. Artinya, penelitian pendidikan berfungsi untuk memecahkan masalah-masalah pendidikan terutama masalah yang berkenaan dengan kualitas proses pendidikan dan pengajaran, mutu hasil pendidikan, relevansi pendidikan, dan lain-lain. Dalam hal ini fungsi penelitian bukan ditujukan untuk pengembangan ilmu, tetapi untuk melakukan perbaikan, penyempurnaan praktik pendidikan, pembaharuan pelayanan publik, termasuk pendidikan.

3. Penelitian kebijakan pendidikan. Fungsi riset ini hampir sama dengan fungsi pemecahan masalah, tetapi dalam hal ini lebih terfokus dalam hal riset kebijakan-kebijakan pendidikan baik kebijakan yang baru akan, sedang, maupun telah dilaksanakan. Hasil penelitian dapat digunakan sebagai bahan masukan bagi para pengambil kebijakan pendidikan baik di tingkat nasional, regional, maupun lokal.

4. Menunjang pembangunan. Riset pendidikan dapat juga dilaksanakan untuk menunjang sektor pembangunan, khususnya berkenaan dengan fungsi dan peran pendidikan dalam pembangunan nasional.- 